\title{
DISTRIBUTION OF TRANSITION ELEMENTS IN CRUSTAL METABASIC IGNEOUS ROCKS
}

\author{
CHRISTIAN NICOLLET and DAUPHIN RICHARD ANDRIAMBOLOLONA* \\ Laboratoire de Pétrologie des Zones Profondes-Laboratoire associé au C.N.R.S. No. 266 , \\ Université des Sciences et Techniques du Languedoc (U.S.T.L.), 34060 Montpellier Cedex \\ (France) \\ Laboratoire de Géochimie du Centre Géologie et Géophysique, Université des Sciences et \\ Techniques du Languedoc (U.S.T.L.), 34060 Montpellier Cedex (France)
}

(Received June 5, 1979; revised and accepted September 12, 1979)

\begin{abstract}
Nicollet, C. and Andriambololona, D.R., 1980. Distribution of transition elements in crustal metabasic igneous rocks. Chem. Geol., 28: 79-90.

The study of transition elements ( $\mathrm{Ti}, \mathrm{V}, \mathrm{Ni}, \mathrm{Cr}, \mathrm{Co}, \mathrm{Cu}, \mathrm{Zn}, \mathrm{Fe}, \mathrm{Mn}$ ) and $\mathrm{Mg}$ in metabasic crustal igneous rocks (amphibolites, granulites, eclogites) suggests that the distribution is not specially affected by medium-and high-grade metamorphism. In some cases, anomalously low contents of $\mathrm{Ni}, \mathrm{Cr}$ and $\mathrm{Cu}$ may be more likely related to a previous lowgrade metamorphic event. It seems that the fractionation of these elements is related to initial magmatic assemblages. It is demonstrated from the elements studied that most of the metabasites have an affinity with extrusive oceanic tholeiites and continental intrusive tholeiites. Thus, the subsequent high-grade metamorphism may be related either to the emplacement of basaltic magmas in the lower continental crust or to the underthrusting of the oceanic crust.
\end{abstract}

\section{INTRODUCTION}

The ancient magmatic rocks are one of the keys to understanding the past geotectonic history of the crust. Unfortunately, these rocks are generally strongly altered by metamorphic processes and their original chemical composition may have changed. Various workers (Pearce et al., 1975; Winchester and Floyd, 1976, etc.) have tried to avoid this difficulty by analysing those trace elements considered to be relatively immobile during metamorphic processes (Y, Zr, Nb, Ti, P, REE). The aim of this paper is to contribute to such studies by analysing in medium- and high-grade crustal metabasites (amphibolites, granulites and eclogites) the transition elements which are also considered to be stable during metamorphism (Jolly and Smith, 1972; Holland and Lambert, 1975; Bridgwater and Collerson, 1976). The advantage of such elements ( $\mathrm{Ti}, \mathrm{V}, \mathrm{Ni}, \mathrm{Cr}, \mathrm{Co}, \mathrm{Cu}, \mathrm{Zn}, \mathrm{Mn}$ ) is that each of them has a specific af-

\footnotetext{
${ }^{*}$ Present address: Service de Géologie, Université de Madagascar, Tananarive (Madagascar).
} 
finity for a given mineralogical phase (e.g., $\mathrm{Ni}$ for olivine). The behaviour of the transition elements during their successive mineralogical transformations and the comparison with the behaviour and contents of such elements in recent volcanic rocks may help to characterize their original magmatic type and geotectonic setting.

For this purpose, we have gathered data published by various authors as well as our own results on the metabasic rocks of the French Massif Central. The study was restricted to basic rocks whose magmatic origin is clearly demonstrated by these authors. These basic terms are chosen using the classification of volcanic rocks: SI $>35$ for tholeiitic basalts, DI $<35$ for alkali basalts, $\mathrm{SiO}_{2}<56 \%$ for basic andesites and basalts related to orogenic zones (Taylor, 1969; Maury, 1976; Andriambololona, 1978; Andriambololona and Dupuy, 1978).

\section{BEHAVIOUR OF TRANSITION ELEMENTS IN METABASIC ROCKS}

The transition element data are plotted in Fig. 1 against the $\mathrm{FeO}^{*} / \mathrm{MgO}$ ratio $\left(\mathrm{FeO}^{*}=\right.$ total $\mathrm{Fe}$ as $\mathrm{FeO}$ ) (Miyashiro and Shido, 1975) for some representative examples of amphibolites, granulites and eclogites. All the series show characteristic trends of volcanic rocks (Miyashiro and Shido, 1975). Cr, $\mathrm{Ni}$ and Co decrease more or less steadily with the $\mathrm{FeO}^{*} / \mathrm{MgO}$ ratio. $\mathrm{Ti}$ and $\mathrm{V}$ generally increase, displaying a trend characteristic of tholeiitic series (Miyashiro and Shido, 1975). However, in some localities (Odenwald amphibolites: Klemm and Weber-Diefenbach, 1971; Madras granulites: Sen and Ray, 1971), Ti remains constant or slightly decreases as in modern volcanics of orogenic zones. In some sequences which have suffered different grades of metamorphism, the behaviour of transition elements is not disturbed (e.g., amphibolites and granulites of the Strona Valley, D.R. Andriambololona, unpublished data, 1978; amphibolites of Greenland found both in amphibolite and granulite facies, Rivalenti and Rossi, 1975).

In spite of these similarities, some differences remain: (1) for a given value of the differentiation index, the transition-element contents are more scattered in metabasites than in volcanic rocks, especially for $\mathrm{Cu}$ and $\mathrm{Zn} ;(2)$ low $\mathrm{Ni}$ and/or Cr contents (up to $5 \mathrm{ppm}$ ) in many metabasites (eclogites of Bohemia: Fediukova and Dudek, 1977; amphibolites of Sardinia: Ricci and Sabatini, 1973 , etc.); (3) depletion in $\mathrm{Cu}$, especially in amphibolites and granulites as already pointed by Andriambololona et al. (1977) and Dupuy et al. (1977) (amphibolites of the Strona Valley; D.R. Andriambololona, unpublished data, 1978; amphibolites of Brazil: Roeser and Müller, 1977; granulites of Bournac: Leyreloup et al., 1977). These contents are close to those found for oceanic gabbros (Table I).

The averaged contents are reported in Tables I and II for metabasic rocks, subdivised according to the previous considerations. 

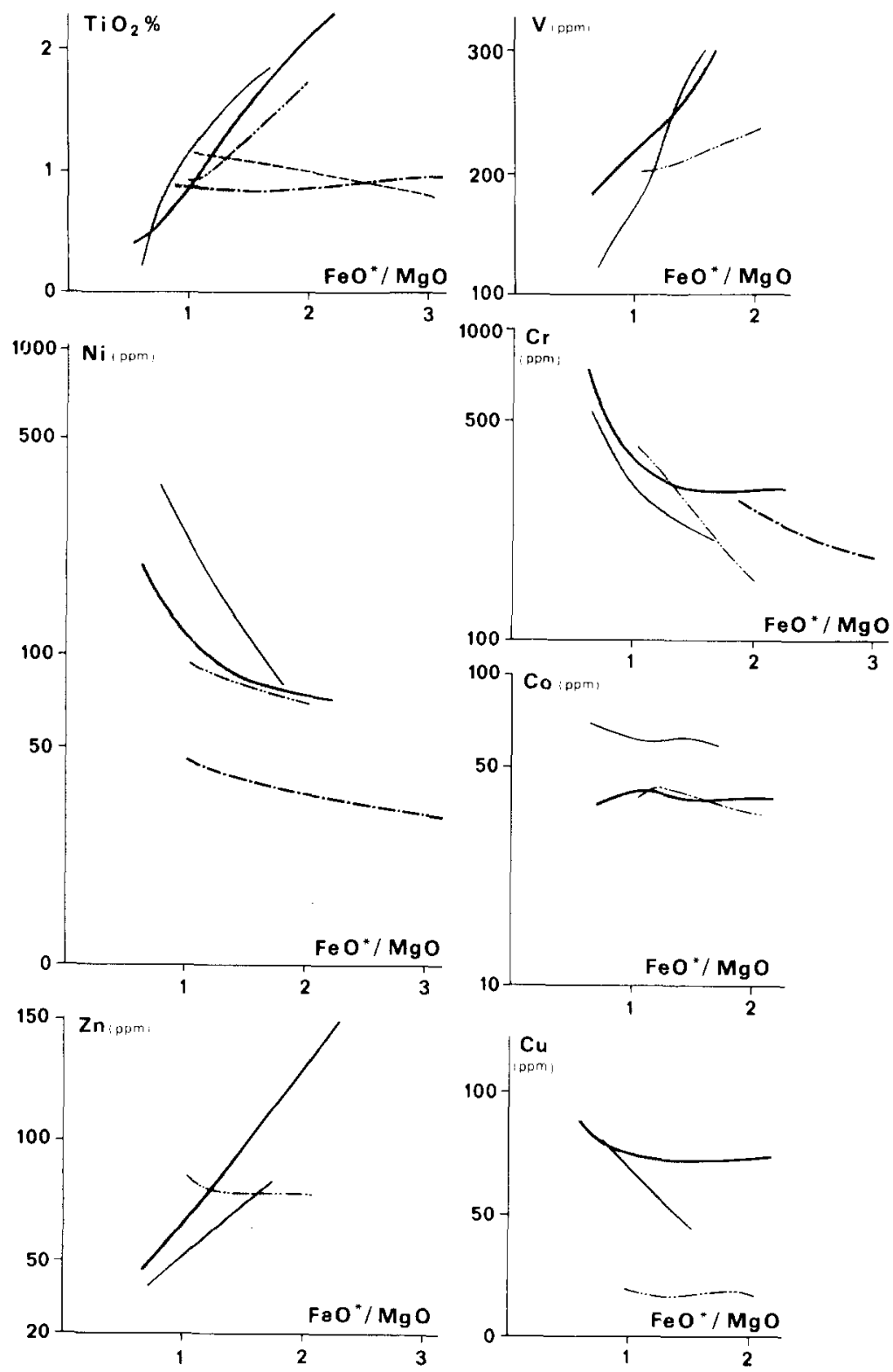

Fig. 1. Variation of the transition elements vs. the $\mathrm{FeO}^{*} / \mathrm{MgO}$ ratio in some representative metabasic rocks suites.

Amphibolites: Acebuches (Dupuy et al., 1979) (-); and Odenwald (Klemm and WeberDiefenbach, 1971) (-. - ) .

Granulites: Bournac (Leyreloup et al., 1977) (- . . -); and Madras (Sen and Ray, 1971) $(---)$.

Eclogites: Hohen Tauern (Richter, 1973) (-).

Shaded area: abyssal tholeiite fields after Andriambololona (1978). 
TABLE I

Average contents for tholeiitic metabasites, abyssal tholeiites and oceanic gabbros

\begin{tabular}{|c|c|c|c|c|c|c|c|c|}
\hline & $n$ & $\mathrm{TiO}_{2}$ & $n$ & $\mathrm{~V}$ & $n$ & $\mathrm{Cr}$ & $n$ & $\mathrm{MnO}$ \\
\hline \multicolumn{9}{|c|}{ Amphibolites: } \\
\hline PI & 4 & $0.56(0.33)$ & 2 & $162(53)$ & 4 & $723(573)$ & 4 & $0.16(0.03)$ \\
\hline PII & 1 & 0.96 & 1 & 188 & 1 & 960 & 1 & 0.18 \\
\hline BII & 22 & $1.16(0.33)$ & 16 & $237(55)$ & 22 & $316(102)$ & 22 & $0.17(0.04)$ \\
\hline BIII & 19 & $1.34(0.32)$ & 10 & $283(73)$ & 19 & $300(132)$ & 19 & $0.19(0.05)$ \\
\hline \multicolumn{9}{|c|}{ Gronulites: } \\
\hline PI & 4 & $0.70(0.19)$ & 4 & $201(37)$ & 4 & $483(274)$ & 4 & $0.14(0.02)$ \\
\hline PII & 4 & $1.28(0.58)$ & 4 & $226(50)$ & 4 & $364(185)$ & 4 & $0.13(0.04)$ \\
\hline BII & 9 & $1.15(0.48)$ & 9 & $202(16)$ & 9 & $372(144)$ & 9 & $0.13(0.04)$ \\
\hline BIII & 2 & $1.98(1.36)$ & 2 & $255(98)$ & 2 & $269(64)$ & 2 & $0.15(0.02)$ \\
\hline \multicolumn{9}{|c|}{ Eclogites: } \\
\hline PI & 7 & $0.45(0.4)$ & 7 & $164(33)$ & 7 & $540(197)$ & 7 & $0.10(0.04)$ \\
\hline PII & 16 & $0.53(0.35)$ & 3 & $235(7)$ & 16 & $457(201)$ & 16 & $0.12(0.07)$ \\
\hline BII & 11 & $0.87(0.43)$ & 6 & $250(45)$ & 11 & $342(124)$ & 11 & $0.14(0.04)$ \\
\hline BIII & 10 & $0.86(0.13)$ & 7 & $226(18)$ & 10 & $325(55)$ & 10 & $0.19(0.08)$ \\
\hline \multicolumn{9}{|c|}{ Olivine abyssal tholeites: } \\
\hline PI & 6 & $0.69(0.18)$ & 2 & $176(36)$ & 6 & $1,022(413)$ & 6 & $0.16(0.01)$ \\
\hline PII & 14 & $0.85(0.41)$ & 14 & $204(34)$ & 14 & $541(154)$ & 14 & $0.16(0.02)$ \\
\hline BII & 12 & $1.14(0.22)$ & 12 & $245(32)$ & 12 & 399 (129) & 12 & $0.16(0.02)$ \\
\hline BIII & 14 & $1.53(0.19)$ & 14 & $292(37)$ & 14 & $256(113)$ & 14 & $0.18(0.02)$ \\
\hline \multicolumn{9}{|c|}{ Plagioclase abyssal tholeiites: } \\
\hline PI & 4 & $0.78(0.20)$ & & - & 4 & $393(122)$ & 4 & $0.15(0.02)$ \\
\hline PII & 5 & $0.75(0.40)$ & 5 & $195(20)$ & 5 & $270(114)$ & 5 & $0.12(0.04)$ \\
\hline BII & 7 & $0.99(0.23)$ & 7 & $218(29)$ & 7 & $296(142)$ & 7 & $0.16(0.05)$ \\
\hline BIII & 11 & $1.24(0.20)$ & 11 & $290(14)$ & 11 & $253(70)$ & 11 & $0.15(0.03)$ \\
\hline \multicolumn{9}{|c|}{ Oceanic gabbros: } \\
\hline PI & 15 & $0.33(0.01)$ & 15 & $153(10)$ & 15 & $1,028(507)$ & 15 & $0.13(0.02)$ \\
\hline BII & 4 & $0.53(0.17)$ & 4 & $223(19)$ & 4 & $210(50)$ & 4 & $0.14(0.01)$ \\
\hline
\end{tabular}

Data are taken for:

(A) Amphibolites, from Knauer et al. (1974); Rivalenti and Rossi (1975); Van Calsteren (1978); Dupuy et al. (1979); unpublished data for French Massif Central (C. Nicollet, 1978), and Strona Valley rocks (D.R. Andriambololona, 1978).

(B) Granulites, from Leyreloup et al. (1977) unpublished data of Strona Valley rocks (D.R. Andriambololona, 1978).

(C) Eclogites, from Bryhni et al. (1969); Richter (1973); Raheim (1976); Van Calsteren (1978); unpublished data for French Massif Central rocks (C. Nicollet, 1978).

For comparison various averaged values are reported for Recent tholeiites compiled by Andriambololona (1978). The subdivision in each rock type is established as follows:

PI: IS $>45, R=\mathrm{Mg} /(\mathrm{Mg}+\mathrm{Fe})>0.72 ; \mathrm{PII}:$ IS $>45,0.72 \geqslant R \geqslant 0.66$.

BI: $45 \geqslant$ IS $\geqslant 35, R>0.72$; BII: $45 \geqslant$ IS $\geqslant 35,0.72 \geqslant R \geqslant 0.66$; BIII: $45 \geqslant$ IS $\geqslant 35,0.66>R \geqslant 0.60$ BIV: $45 \geqslant$ IS $\geqslant 35,0.60>R$.

$n=$ number of samples in the four groups: ()$=$ standard deviation.

* Total Fe as FeO. 


\begin{tabular}{|c|c|c|c|c|c|c|c|c|c|c|c|}
\hline$n$ & $\mathrm{FeO}^{*}$ & $n$ & Co & $n$ & $\mathrm{Ni}$ & $n$ & $\mathrm{Cu}$ & $n$ & $\mathrm{Zn}$ & $\mathrm{Ti} / \mathrm{V}$ & $\mathrm{Mg} / \mathrm{Ni}$ \\
\hline 4 & $7.96(1.66)$ & 3 & $54(15)$ & 2 & $214(234)$ & 2 & $37(35)$ & 2 & $59(21)$ & $21(7)$ & $313(243)$ \\
\hline 1 & 8.42 & 1 & 52 & 1 & 358 & 1 & 13 & 1 & 58 & 30 & 154 \\
\hline 22 & $9.05(1.75)$ & 17 & $59(8)$ & 20 & $121(57)$ & 16 & $58(55)$ & 16 & $67(18)$ & $29(2)$ & $389(45)$ \\
\hline 19 & $9.22(2.42)$ & 12 & $62(14)$ & 17 & $111(87)$ & 10 & $42(56)$ & 10 & $78(29)$ & $28(3)$ & $421(81)$ \\
\hline 4 & $8.43(2.65)$ & 4 & $37(12)$ & 4 & $104(44)$ & 4 & $17(4)$ & 4 & $69(17)$ & $21(3)$ & $554(122)$ \\
\hline 4 & $10.93(1.53)$ & 4 & $70(12)$ & 4 & $191(117)$ & 4 & $22(16)$ & 4 & $95(42)$ & $34(9)$ & 319 (102) \\
\hline 9 & 9.07 (1.18) & 9 & 49 (7) & 9 & $102(54)$ & 9 & 17 (1) & 9 & 84 (9) & $34(5)$ & $473(84)$ \\
\hline 2 & $9.84(1.63)$ & 2 & $58(25)$ & 2 & $106(51)$ & 2 & $24(10)$ & 2 & $136(31)$ & $46(25)$ & $429(153)$ \\
\hline 7 & $6.80(0.68)$ & 7 & $51(13)$ & 7 & $463(215)$ & 7 & $74(22)$ & 4 & $49(13)$ & $16(6)$ & $142(28)$ \\
\hline 16 & $7.53(1.18)$ & 16 & $40(25)$ & 16 & $143(73)$ & 16 & $84(59)$ & 14 & $53(10)$ & $14(2)$ & $407(62)$ \\
\hline 11 & $8.51(1.34)$ & 11 & $46(22)$ & 11 & $99(45)$ & 10 & $73(36)$ & 9 & $64(21)$ & 21 (3) & $503(71)$ \\
\hline 10 & $9.90(1.25)$ & 10 & $48(18)$ & 9 & $92(41)$ & 4 & $67(38)$ & 2 & $92(47)$ & $23(1)$ & $535(84)$ \\
\hline 6 & $8.56(0.55)$ & 7 & $57(2)$ & 6 & $423(216)$ & 6 & $91(8)$ & 2 & $63(10)$ & - & $122(119)$ \\
\hline 14 & $8.79(0.63)$ & 14 & $56(12)$ & 14 & $216(48)$ & 14 & $91(27)$ & $\overline{14}$ & $64(4)$ & $25(13)$ & $277(69)$ \\
\hline 12 & $8.86(0.25)$ & 12 & $53(16)$ & 12 & $168(69)$ & 12 & $82(14)$ & 12 & $67(4)$ & $28(6)$ & $321(134)$ \\
\hline 14 & $9.99(1.07)$ & 14 & $48(15)$ & 14 & $122(51)$ & 14 & $76(18)$ & 14 & $80(14)$ & $31(5)$ & 394 (169) \\
\hline 4 & $8.01(1.25)$ & & - & 4 & $144(22)$ & 4 & $66(18)$ & & - & - & $403(68)$ \\
\hline 5 & $6.80(1.67)$ & 5 & 34 (13) & 5 & $102(23)$ & 5 & $73(25)$ & 5 & $56(7)$ & $23(12)$ & 449 (149) \\
\hline 7 & $8.29(0.90)$ & 7 & $35(6)$ & 7 & $108(37)$ & 7 & $67(5)$ & 7 & $61(12)$ & $27(7)$ & $443(164)$ \\
\hline 11 & $9.02(0.74)$ & 11 & 42 (4) & 11 & $96(20)$ & 11 & $62(19)$ & & & $26(4)$ & $472(104)$ \\
\hline 15 & $5.70(0.19)$ & 15 & $41(16)$ & 15 & $219(30)$ & 15 & $64(6)$ & & & $13(1)$ & $277(67)$ \\
\hline 4 & $6.63(0.85)$ & 4 & 39 (19) & 4 & $105(35)$ & 4 & $18(4)$ & & & $14(5)$ & $476(93)$ \\
\hline
\end{tabular}

\section{COMPARISON BETWEEN METABASIC ROCKS AND CORRESPONDING NON- METAMORPHIC VOLCANICS}

Main components factorial analysis applying to the first series of transition elements has been carried out both for basalts and metabasic rocks and reported graphically in Fig. 2. The following results were obtained from the program printout: the lower right-hand side of this figure is a plot of loadings on factors $F_{1}$ and $F_{2}$. This figure divides the elements in two groups: $\mathrm{Ni}, \mathrm{Cr}$ and $\mathrm{Mg}$, and $\mathrm{Zn}$, $\mathrm{Ti}$ and $\mathrm{Fe}$; in each group, these elements display a strong positive correlation indicating a close similarity in their behaviour; the eigenvalues $F_{1}$ and $F_{2}$ comprise a total of $67 \%$ of the information available for separating the magma types; the eigenvectors show that these two functions are:

$$
\begin{aligned}
F_{1}= & -0.037 x^{\prime}{ }_{\mathrm{MnO}}+0.519 x^{\prime}{ }_{\mathrm{MgO}}+0.018 x^{\prime} \mathrm{TiO}_{2}+0.158 x_{\mathrm{Fe}_{2} \mathrm{O}_{3}}+ \\
& 0.508 x_{\mathrm{Cr}}^{\prime}+0.384 x^{\prime}{ }_{\mathrm{Co}}+0.518 x^{\prime}{ }_{\mathrm{Ni}}+0.171 x_{\mathrm{Cu}}^{\prime}-0.016 x_{\mathrm{Zn}} \\
F_{2}= & -0.376 x_{\mathrm{MnO}}^{\prime}+0.047 x^{\prime} \mathrm{MgO}-0.555 x^{\prime} \mathrm{TiO}_{2}-0.517 x_{\mathrm{Fe}_{2} \mathrm{O}_{3}}+ \\
& 0.128 x_{\mathrm{Cr}}^{\prime}-0.065 x_{\mathrm{Co}}^{\prime}+0.020 x^{\prime}{ }_{\mathrm{Ni}}-0.032 x_{\mathrm{Cu}}^{\prime}-0.501 x_{\mathrm{Zn}}^{\prime}
\end{aligned}
$$




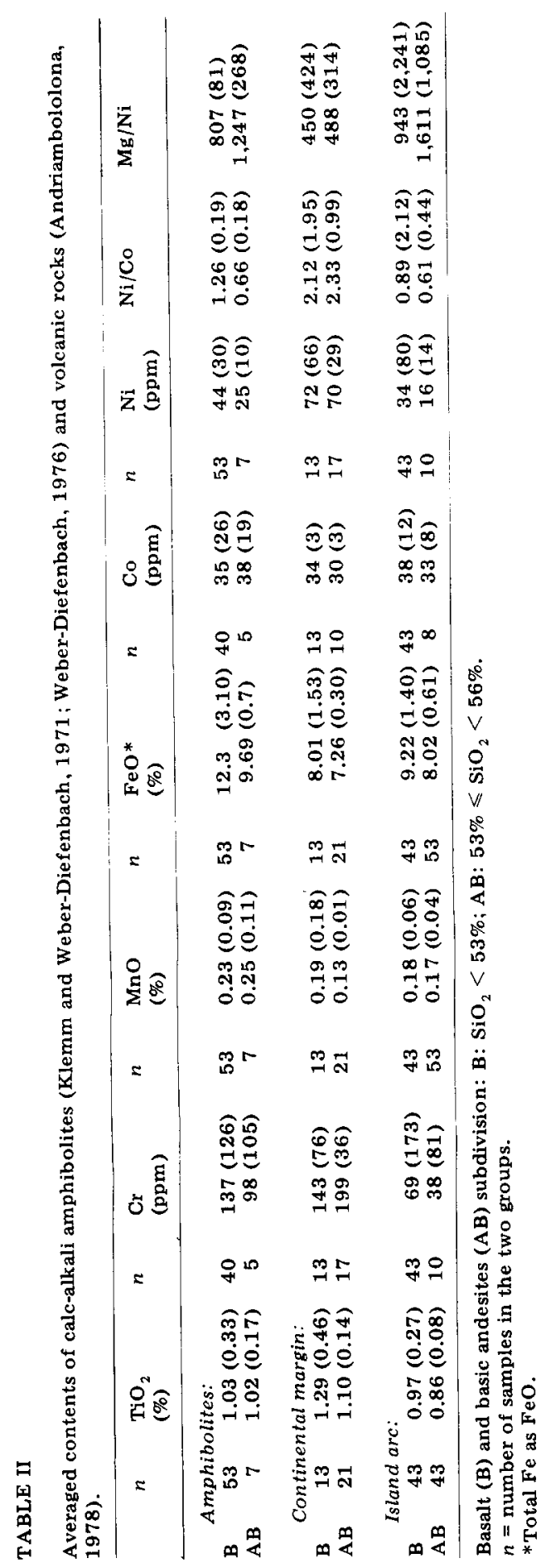


TABLE III

Mean and standard deviations obtained for 93 selected basic rocks

\begin{tabular}{llllllllll}
\hline $\begin{array}{l}\mathrm{MnO} \\
(\%)\end{array}$ & $\begin{array}{l}\mathrm{MgO} \\
(\%)\end{array}$ & $\begin{array}{l}\mathrm{TiO}_{2} \\
(\%)\end{array}$ & $\begin{array}{l}\mathrm{Fe}_{2} \mathrm{O}_{3} \\
(\%)\end{array}$ & $\begin{array}{l}\mathrm{Cr} \\
(\mathrm{ppm})\end{array}$ & $\begin{array}{l}\mathrm{Co} \\
(\mathrm{ppm})\end{array}$ & $\begin{array}{l}\mathrm{Ni} \\
(\mathrm{ppm})\end{array}$ & $\begin{array}{l}\mathrm{Cu} \\
(\mathrm{ppm})\end{array}$ & $\begin{array}{l}\mathrm{Zn} \\
(\mathrm{ppm})\end{array}$ \\
\hline $\bar{x}$ & 0.166 & 9.45 & 1.65 & 11.22 & 419 & 54 & 219 & 79 & 82 \\
$s$ & 0.024 & 4.10 & 0.91 & 1.85 & 389 & 17 & 268 & 40.2 & 25 \\
\hline
\end{tabular}

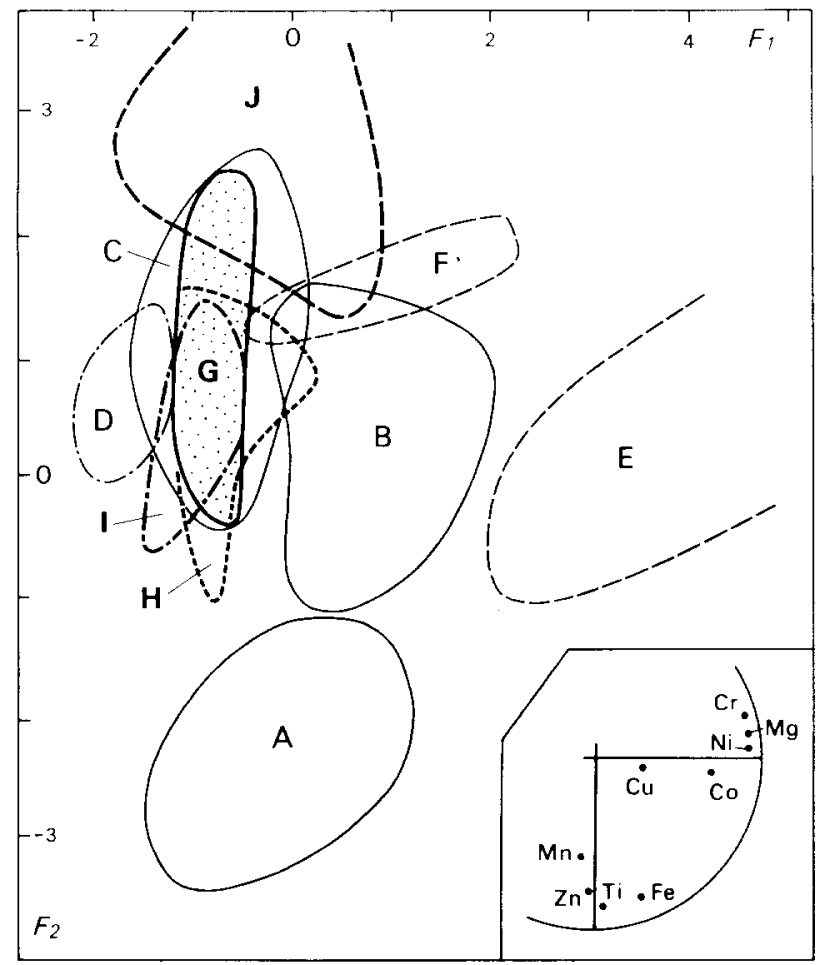

Fig. 2. Plot of factors score $F_{1}$ and $F_{2}$ for volcanic rocks (picrites and basalts) and metabasites (data from Table I). $F_{1}+F_{2}$ account for $67 \%$ of the total variance with factor 1 contributing $37 \%$.

$A=$ alkali basalts; $B=$ extrusive continental and island tholeiites; $C=$ abyssal tholeiites; $D=$ orogenic volcanic rocks; $E=$ picrites of continental and island tholeiites; $F=$ picrites of abyssal tholeiites; $G=$ eclogites; $H=$ granulites; $I=$ amphibolites; and $J=$ picrites of metabasites.

with $x^{\prime}=(x-\bar{x}) / s ; \bar{x}$ and $s$ are respectively mean and standard deviations obtained for 93 selected basic rocks and reported in Table III.

Fig. 2 shows that the transition elements discriminate the different volcanic rocks (Andriambololona, 1978). The three types of metabasites cluster in the abyssal tholeiites field. This kind of representation accounts for the different 


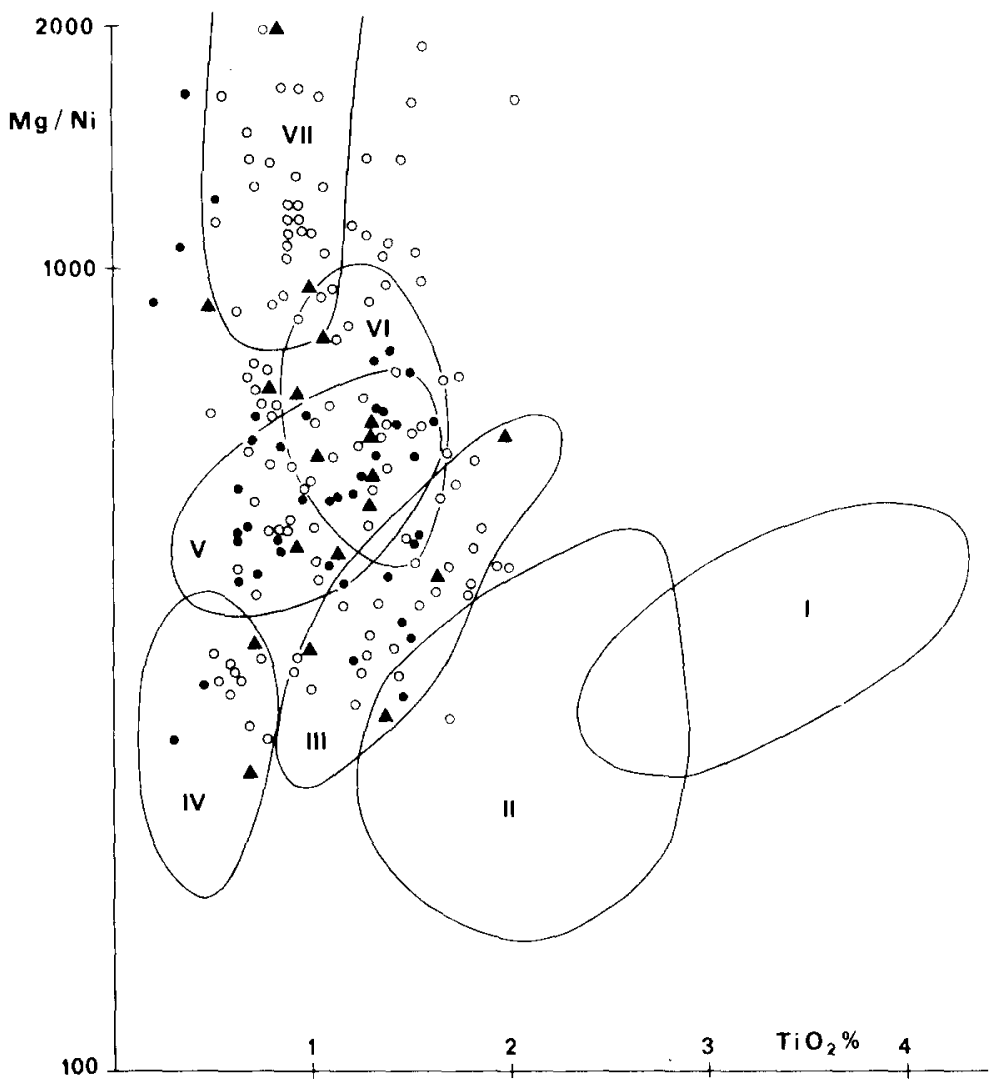

Fig. 3. $\mathrm{Mg} / \mathrm{Ni}$ ratio vs. $\mathrm{TiO}_{2}$.

Open circles: amphibolites (Van de Kamp, 1969; Prato, 1970; Klemm and Weber-

Diefenbach, 1971; Knauer et al., 1974; Rivalenti and Rossi, 1975; Weber-Diefenbach, 1976;

Dupuy et al., 1979; unpublished data for Rouergue, French Massif Central: C. Nicollet

(1978); and Strona Valley: D.R. Andriambololona (1978).

Triangles $=$ granulites $($ Leyreloup et al., 1977; unpublished data for French Massif Central:

Marchand; and Strona Valley: Andriambololona (1978).

Full circles = eclogites (Bryhni et al. 1969; Ernst, 1977: Matthes and Seidel, 1977; Miller, 1970; Råheim, 1976; Richter, 1973; unpublished data for Rouergue: Nicollet (1978).

Continuous lines define the fields occupied by alkali and transitional basalt (I); extrusive continental tholeiites (II); olivine abyssal tholeiites and oceanic island tholeiites (III); oceanic gabbros and olivine normative dolerites (IV); plagioclase abyssal tholeiites, quartz-normative dolerites and Skaergaard gabbro (Wager and Mitchell, $1951(V)$; continental margin calc-alkali rocks $(V I)$; and island arc tholeiites and calc-alkali rocks (VII).

transition elements but remains restrictive because of the scarcity of the samples in which all transition elements are available. In consequence, another graph, $\mathrm{Mg} / \mathrm{Ni}$ vs. $\mathrm{TiO}_{2}$ using only three elements, but allowing us to consider increased numbers of samples, is presented in $\mathrm{Fig}$. 3. $\mathrm{TiO}_{2}$ displays large variations and specially discriminates between alkali and tholeiitic affinities and 
the $\mathrm{Mg} / \mathrm{Ni}$ ratio may control the olivine fractionation (Gunn, 1971). Moreover, this graph discriminates between intrusive and extrusive rocks. It shows that most of the metabasites cluster in the field of oceanic tholeiites, gabbros and dolerites except some examples which lie in the field of orogenic volcanic rocks (Odenwald amphibolites: Klemm and Weber-Diefenbach, 1971; Tyrol amphibolites: Weber-Diefenbach, 1976). None of the series studied falls in the field of the continental tholeiites nor in that of alkali basalts. However, Ricci and Sabatini (1978) have shown (by analysing Y, Zr, Nb, La and Ce) the alkaline affinity of the Sardinian amphibolites. This affinity is corroborated by high $\mathrm{Ti}, \mathrm{V}$ and $\mathrm{Ti} / \mathrm{V}$ contents despite low $\mathrm{Ni}$ and $\mathrm{Cr}$ contents.

\section{DISCUSSION}

The similarity in behaviour of the transition elements in the metabasites and in the volcanic rocks, suggests that the magmatic fractionation trend is preserved during the medium- and high-grade metamorphic events. In consequence, the distribution of the transition elements is more likely related to the mineralogical phases of the original basalt than to those of the corresponding metabasite as claimed by Fediukova and Dudek (1977). Although olivine and spinel are generally absent in metabasites, the rapid decrease of $\mathrm{Cr}$ and $\mathrm{Ni}$ during the earliest step of differentiation suggests a fractionation due to olivine and spinel. These two minerals are the only ones with partition coefficients high enough to deplete $\mathrm{Ni}$ and $\mathrm{Cr}$ rapidly during the differentiation (Frey et al. 1974). We believe thus that metamorphic transformations do not necessarily change the chemical composition of medium-and high-grade basic rocks, as was suggested by Forbes (1965) and Bryhni et al. (1969).

In this hypothesis, the very low $\mathrm{Cr}, \mathrm{Ni}$ and $\mathrm{Cu}$ contents of some metabasites could be explained by some event earlier than the medium- or high-grade metamorphism. However, Andriambololona and Chikhaoui (in prep.) have shown that $\mathrm{Cr}, \mathrm{Ni}$ and $\mathrm{Cu}$ may be depleted during low-grade metamorphism. Furthermore, Miyashiro et al. (1969), Thompson (1973), Bonatti et al. (1975), Pamic, (1974), and C.G. Engel and Fisher (1975) argued that the low $\mathrm{Cu}$ content of oceanic gabbros is due to seawater alteration. Such events may affect the rocks before the high-grade metamorphism. Low $\mathrm{Cr}$ and $\mathrm{Ni}$ contents of Bohemian eclogites (Fediukova and Dudek, 1977) and Cu depletions of some eclogites of the French Massif Central (C. Nicollet, unpublished data, 1978) showing gabbroic characters (honeycomb structure and low $\mathrm{TiO}_{2}$ content) may be related to such processes.

Most of these metabasites have an affinity with oceanic tholeiites. Some of them may have a continental affinity (granulites of Bournac: A. Leyreloup, pers. commun., 1978); or quartz dolerites: Råheim, 1976). Only a few amphib olites have a calc-alkaline affinity. These observations are in agreement with the conclusions of Matthes (1978) for the German eclogites but in disagreement with the conclusions of Forbes (1965) who believes that the scarcity of alkali eclogites is only due to the alkali loss during metamorphism. 


\section{CONCLUSIONS}

This study suggests that the distribution and the behaviour of the transition elements in metabasites is not specially affected by medium- and highgrade metamorphism. The depletion of $\mathrm{Ni}, \mathrm{Cr}$ and $\mathrm{Cu}$ in some localities may be more likely the result of a previous low-grade event. In metabasites, the fractionation of transition elements is related to the initial magmatic mineralogic phases of the original basalt. Thus, these elements appear very useful in the determination of the original geochemical affinity of the metabasic rocks. However, it is very difficult to separate, with transition elements alone, the extrusive oceanic tholeiites and the intrusive continental tholeiites. The two rock types with tholeiitic affinity are the most widespread among the metabasites. This feature appears logical by reference to the respective proportions of the actual magmatic type (A.E.J. Engel et al., 1965). The subsequent high-grade metamorphism may be related either to the emplacement of basaltic magmas in the lower continental crust (Griffin and Heier, 1973), or to the underthrusting of the oceanic crust (Miyashiro, 1972).

\section{ACKNOWLEDGEMENTS}

Financial support was provided by Laboratoire de Géochimie du Centre Géologie et Géophysique. P. Matte is gratefully acknowledged for his help in the English translation.

\section{REFERENCES}

Andriambololona, R., 1978. Étude de la répartition et du comportement des éléments de transition: $\mathrm{Ti}, \mathrm{V}, \mathrm{Cr}, \mathrm{Co}, \mathrm{Ni}, \mathrm{Cu}, \mathrm{Zn}$ dans les différentes séries volcaniques - Application aux roches volcaniques anciennes. Thesis, University of Montpellier II, Montpellier.

Andriambololona, R. and Dupuy, C., 1978. Répartition et comportement des éléments de transition dans les roches volcaniques, I. Cuivre et zinc. Bull. Bur. Rech. Géol. Minières (Fr.), Sect. 2, 2: 121-138.

Andriambololona, R., Dupuy, C. and Leyreloup, A., 1977. Les éléments de transition dans les enclaves catazonales de Bournac (Velay, Massif Central français). C.R. Acad. Sci. Paris, 284: 875-878.

Bonatti, E., Honnorez, J., Kirst, P. and Radicati, F., 1975. Metagabbros from the midAtlantic ridge at $06^{\circ} \mathrm{N}$ : contact-hydrothermal-dynamic metamorphism beneath the axial valley. J. Geol., 83: $61-78$.

Bridgwater, D. and Collerson, K.D., 1976. The major petrological and geochemical characters of the 3,600 m.y. Vivak gneisses from Labrador. Contrib. Mineral. Petrol., 54 : $43-59$.

Bryhni, I., Bollingberg, H.J. and Graff, P.R., 1969. Eclogites in quartzo-feldspathic gneisses of Nordjord, west Norway. Nor. Geol. Tidssk., 49: 193-225.

Dupuy, C., Leyreloup, A. and Vernières, J., 1977. The lower continental crust of the Massif Central (Bournac, France), with special references to R.E.E., U and Th - Composition, évolution, heat production. Congr. Géochim., UNESCO Paris.

Dupuy, C., Dostal, J. and Bard, J.P., 1979. Trace element geochemistry of Paleozoic amphibolites from S.W. Spain. Tschermaks Mineral. Petrogr. Mitt., 26: 87-93. 
Engel, A.E.J., Engel, C.G. and Havens, R.G., 1965. Chemical characteristics of oceanic basalts and the upper mantle. Geol. Soc. Am. Bull., 76: 719-734.

Engel, C.G. and Fisher, R.L., 1975. Granitic to ultramafic rock complexes of the Inuian ocean ridge system, western Indian Ocean. Geol. Soc. Am. Bull., 86: 1553-1578.

Ernst, W.G., 1977. Mineralogic study of eclogitic rocks from Alpe Aranci, Lepontine Alps, southern Switzerland. J. Petrol., 18:371-398.

Fediukova, E. and Dudek, A., 1977. Trace elements of the Moldanubian eclogites. Neues Jahrb. Mineral., Abh., 130: 187-207.

Forbes, R.B., 1965. The comparative chemical composition of eclogite and basalt. J. Geophys. Res., 70: 1515-1521.

Frey, F.A., Bryan, W.B. and Thompson, G., 1974. Atlantic Ocean floor: geochemistry and petrology of basalts from Legs 2 and 3 of the Deep Sea Drilling Project. J. Geophys. Res., 79: 5507-5527.

Griffin, W.L. and Heier, K.S., 1973. Petrological implications of some corona structures. Lithos, 6: 315-335.

Gunn, B.M., 1971. Trace elements partition during olivine fractionation of Hawaii basalts. Chem. Geol., 8: 1-13.

Holland, J.C. and Lambert, R., 1975. The chemistry and origin of the Lewisian gneisses of the Scottish assemblages and sub-crustal accretion. Precambrian Res., 2: 161-188.

Jolly, W.T. and Smith, R.E., 1972. Degradation and metamorphic differentiation of the Keweenawan tholeiitic lavas of northern Michigan, U.S.A. J. Petrol., 13: 273-309.

Klemm, D.D. and Weber-Diefenbach, K., 1971. Geochemische Untersuchungen an Amphiboliten und Dioriten des nördlichen Odenwald. Neues Jahrb. Mineral., Abh., 116: 80-111.

Knauer, E., Okrusch, M., Richter, P., Schmidt, K. and Schubert, W., 1974. Die metamorphe Basit-Ultrabasit Assoziation in der Böllsteiner Gneiskuppel, Odenwald. Neues Jahrb. Mineral,, Abh., 122: 186-228.

Leyreloup, A., Dupuy, C. and Andriambololona, R., 1977. Catazonal xenoliths in French Neogene volcanic rocks: constitution of the lower crust, 2 , Chemical composition and consequences of the evolution of the French Massif Central Precambrian crust. Contrib. Mineral. Petrol., 62: 283-300.

Matthes, S., 1978. The eclogites of southern Germany - A summary. Neues Jahrb. Mineral., Monatsh., 3: 93-109.

Matthes, S. and Seidel, E., 1977. Das Eklogitvorkommen des kristallinen Grundge birges in NE-Bayern, X. Bestehen genetische Beziehungen zwischen Eklogit und Metagabbro innerhalb des Münchberger Gneisgebietes? Neues Jahrb. Mineral., Abh., 129: 269291.

Maury, R.C., 1976. Contamination (par l'encaissant et les enclaves) et cristallisation fractionnée de séries volcaniques alcalines, continentales (Massif Central français) et océaniques (Pacifique Central): L'origine des laves acides. Thesis University of Paris, Paris, 455 pp.

Miller, C., 1970. Petrology of some eclogites and metagabbros of the Oetztal Alps, Tirol, Austria. Contrib. Mineral. Petrol., 28: 42-56.

Miyashiro, A., 1972. Metamorphism and related magmatism in plate tectonics. Am. J. Sci. $272,629-656$.

Miyashiro, A. and Shido, F., 1975. Tholeiitic and calc-alkalic series in relation to the behaviors of titanium, vanadium, chromium, and nickel. Am. J. Sci., 275: 265-277.

Miyashiro, A., Shido, F. and Ewing, H., 1969. Diversity and origin of abyssal tholeiites from the Mid-Atlantic ridge near $24^{\circ}$ and $30^{\circ}$ North latitude. Contrib. Mineral. Petrol., 23: $38-52$.

Pamic, J.J., 1974. Alpine-type gabbros within the Krivaja-Konjuh ultramafic massif in the ophiolite zone of the Dinarides, Yugoslavia. Tschermaks Mineral. Petrogr. Mitt., 21: $261-279$. 
Pearce, T.H., Gorman, B.E., Birkett, T.C., 1975. The $\mathrm{TiO}_{2}-\mathrm{K}_{2} \mathrm{O}-\mathrm{P}_{2} \mathrm{O}_{5}$ diagram: a method of discriminating between oceanic and non-oceanic basalts. Earth Planet. Sci. Lett., 24: $419-426$.

Prato, V.A.G., 1970. Amphibolites from the Grand Forks Quadrangle of British Columbia, Canada. Geol. Soc. Am. Bull., 81: 763-782.

Råheim, A., 1976. Petrology of eclogites and surrounding schists from the Lyell Highway-Collinwood River area. J. Geol. Soc. Aust., 23: 313-327.

Ricci, C.A. and Sabatini, G., 1973. Relazioni fra rocce granitiche e metamorfiche nella Sardegna Centro-settentrionale, Nota V. Le anfiboliti della zona Esporlatu--Anela. Mineral. Petrogr. Acta, 19: 195-214.

Ricci, C.A. and Sabatini, G., 1978. Petrogenetic affinity and geodynamic significance of metabasic rocks from Sardinia, Corsica and Provence. Neues Jahrb. Mineral., Monatsh., 1: $23-38$.

Richter, W., 1973. Vergleichende Untersuchungen an ostalpinen Eklogiten. Tschermaks Mineral, Petrogr. Mitt., 19: 1-50.

Rivalenti, G. and Rossi, A., 1975. Geochemistry of Precambrian amphibolites in an area near Fiskenaesset, southwest Greenland. Bull. Soc. Geol. Ital., 94: 27-49.

Roeser, M. and Müller, G., 1977. Variation and different ages of Precambrian amphibolites. Mariana district, Minas Geraes, Brazil. Neues Jahrb. Mineral., Abh., 130: 39-48.

Sen, S.K. and Ray, S., 1971. Hornblende--pyroxene granulites versus pyroxene granulites: a study from the type charnockite area. Neues Jahrb. Mineral., Abh., 115: 291-314.

Taylor, S.R., 1969. Trace element chemistry of andesites and associated calc-alkaline rocks. Proc. of Andesite Conference. Int. Upper Mantle Proj., Sci. Rep., 16: 43-63.

Thompson, G., 1973. Trace-element distribution in fractionated oceanic rocks, 2. Gabbros and related rocks. Chem. Geol., 12: 99-111.

Van Calsteren, P.W.C., 1978. Geochemistry of the polymetamorphic mafic-ultramafic complex at Cabo Ortegal (NW Spain). Lithos, 11:61-72.

Van de Kamp, P.C., 1969. Origin of amphibolites in the Beartooth Mountains, Wyoming and Montana: new data and interpretation. Geol. Soc. Am. Bull., 80: 1127-1136.

Wager, L.R. and Mitchell, R.L., 1951. The distribution of trace elements during strong fractionation of basic-magma - a further study of the Skaergaard intrusion, east Greenland. Geochim. Cosmochim. Acta, 1: 129-208.

Weber-Diefenbach, K., 1976. Zur Geochemie und Metamorphose von Amphiboliten der Greiner Schiefer-Serie (Zillertaler Alpen, Tirol). Tschermaks Mineral. Petrogr. Mitt., 23: $1-22$.

Winchester, J.A. and Floyd, P.A., 1976. Geochemical magma type discrimination: application to altered and metamorphosed basic igneous rocks. Earth Planet. Sci. Lett., 28: $459-469$. 